\title{
堆積性の岩石の破壊勒性に及ぼす 温度および封圧の影響
}

\author{
船津貴弘 1 - 瀬戸政宏 2 -島田英樹 3 - 松井紀久男 4 \\ 1工修 九州大学大学院 工学府地球資源システム工学専攻（†812-8581 福岡市東区箱崎6-10-1） \\ E-mail:t-funatsu@aist.go.jp \\ 2正会員 工博 産業技術総合研究所 企画本部（†100-8921 東京都千代田区霞ヶ関1-3-1） \\ 3正会員 工博 九州大学助教授 工学研究院地球資源システム工学専攻（テ812-8581 福岡市東区箱崎6- \\ 10-1) \\ 4正会員 工博 九州大学教授 工学研究院地球資源システム工学専攻（†812-8581 福岡市東区箱崎6-10-
}

1)

\begin{abstract}
岩石の破壊勒性に及ぼす温度および封圧の影響を明らかにするために, 最高温度 $200^{\circ} \mathrm{C}$, 最大封圧 $9 \mathrm{MPa}$ の範囲で来待砂岩と田下凝灰岩を用いてSENRBB(Single Edge-Notched Round Bar in Bending)試験法による 破壊靰性試験を実施し, 実験的検討を行なった.その結果, 来待砂岩, 田下凝灰岩の破壊勒性は温度の上昇 とともに変化することを示した.また，来待砂岩，田下凝灰岩の破壊靭性は封圧の上昇とともに増加するこ とを示した.
\end{abstract}

Key Words : fracture toughness, Kimachi sandstone, Tage tuff, elevated temperature, confining pressure

\section{1.緒言}

高レベル放射性廃棄物の地層処分, 産業廃棄 物,LPG,LNG の地下貯蔵,ならびに生活空間,輸送空間 としての大深度地下の利用等において,長期的な地下 の利用が計画され一部は実現されつつある.このよう な地下岩盤の長期的な利用に関しては,その設計や健 全性の評価が極めて重要であるが,その長期的な利用 を考える上では,岩盤のクリープ特性や対象となる地 下の外力条件や環境条件により生じる応力腐食割れ などの影響を総合的に検討する必要がある.通常,岩石 内部には潜在き裂が含まれており,地下の環境条件や 外力条件の影響によって,長期的には潜在き裂の様相 が変化し,岩盤構造物の安定性に影響を及ぼすものと 考えられる.したがって,岩盤の長期的安定性について 検討するためには,基礎的な岩石の力学特性として岩 石のき裂進展抵抗である破壊勒性に及ぼす環境条件 や外力条件などの影響に関する検討が重要である.例 えば,高レベル放射性廃棄物の地層処分では,地下 $300 \mathrm{~m}$ 以深の地下に岩盤構造物を建設することが想定 されており ${ }^{1)}$,外力条件として高い地殼応力, 環境条件 としては,地下水や廃棄体から放出される熱,さらには
岩盤が有する地熱などの作用を考慮する必要がある.

岩石の破壊勒性に及ぼす温度に関する従来の研究 として, Meredith et al.は,花崗岩および斑レイ岩を用い て $20^{\circ} \mathrm{C} \sim 400^{\circ} \mathrm{C}$ 範囲で検討を行なっている ${ }^{2)}$.その 結果,破壊勒性は $20^{\circ} \mathrm{C} \sim 100^{\circ} \mathrm{C}$ 範囲で温度の上昇に 伴い増加するが $100^{\circ} \mathrm{C}$ 以上では温度の上昇に伴い减 少することを示した.また,Al-Shayea et al.は,石灰岩を 用いて室温から $116^{\circ} \mathrm{C}$ 範囲で破壊勒性に及ぼす温 度の影響について検討し ${ }^{3)}$,その破壊靭性は室温から

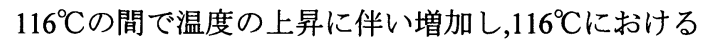
破壊靰性は室温条件における破壊靭性に比べて約 $25 \%$ 増加することを示した.

封圧下の岩石の破壊靰性に関する研究としては,小 林らによる凝灰岩, 花岡岩, 砂岩,大理石を用いた封圧 $24.5 \mathrm{MPa}$ までの引き裂き試験 ${ }^{4)}$, 石塚らによる SENBB(Single Edge Notch Beam under Three Point Bending)試験と SENRBB(Single Edge-Notched Round Bar in Bending)試験による花崗岩と安山岩を用いた 15MPa までの試験 ${ }^{5)}$,Vasarhelyi による片麻岩を用いた 封圧 $60 \mathrm{MPa}$ までの範囲で SENBB 試験 ${ }^{6)}$ による検討 などが挙げられる.これらの検討結果によれば,岩石の 破壊勒性は封圧の上昇に伴い増加すること,さらに,石 


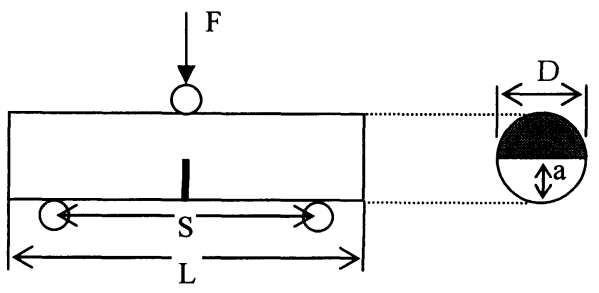

(D:試験片直径,L:試験片長さ,S:支点ローラ間距離,a:ノッチ 長さ) 各パラメータの具体的な数值は後述する

図-1 SENRBB 試験片形状

塚ら,Vasarhelyi は両者の関係が一次関数的であるこ とを示している.また,松木らは花崗岩と凝灰岩を用い て封圧 29.4MPa の範囲で SR(Short Rod) 試験および C-RCT(Chevron-notched Round Compact Tension) 試験 を行なっている 7).その結果,封圧に伴いき裂進展抵抗 が増加すること,さらに,き裂進展抵抗の異方性が顕著 になることを示した.

以上述べたように,岩石の破壊勒性に及ぼす温度や 封圧の影響に関する研究が実施されているが,温度の 影響については花崗岩などの結晶質岩以外の堆積岩 についてはほとんど研究事例がないのが現状であり, 封圧の影響については未だ見当の余地が残されてい る.

したがって,本研究においては,岩石試料として堆積 性岩石である来待砂岩と田下凝灰岩を用 い,SENRBB(Single Edge-Notched Round Bar in Bending) 試験により破壊勒性に及ぼす温度ならびに封圧の影 響について実験的な検討を行なった.

\section{2.破壊靯性評価法}

本研究における破壊勒性試験ではSENRBB試験を 行なった.SENRBB試験片の形状を図-1に示す.この SENEBB試験の特徴は,ノッチとしてストレートノッ チを採用していること,また,三点曲げにより載荷を行 なうことから試験片の準備が容易で試験方法が簡便 であることが挙げられる.ただし,SENRBB試験では岩 石の非線形挙動が考慮されておらず,破壊勒性を過小 評価する可能性がある.これまでの研究で,岩石の破 壊靭性はき裂の進展とともに増加し,き裂が岩石固有 のある長さに到達するとほぼ一定になることが知ら れている7゙.このような破壊靭性がき裂長さとともに 増加する傾向は,き裂の成長に伴ってプロセスン゙ーン が拡大し,プロセスゾーンの寸法が定常状態になって はじめて岩石固有の破壊靭性に達するためである7).

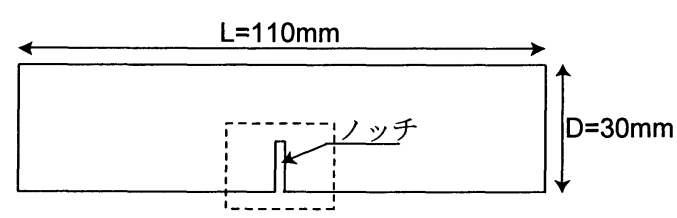

(a) 試験片模式図

(b) ノッチ長さ $a_{1} \mathrm{~mm}$<smiles>[CH]1C2CC[I-]1C2</smiles>

(c) ノッチ長さ $a_{2} \mathrm{~mm}$

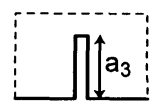

(d) ノッチ長さ $a_{3} \mathrm{~mm}$

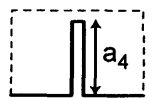

(e) ノッチ長さ $a_{4} \mathrm{~mm}$

図-2＼cjkstart無次元コンプライアンスとき裂長さとの較正を 行なうために用いた,ノッチ長さを $\mathrm{a}_{1} \sim \mathrm{a}_{4}$ まで変 えた試験片の模式図

従って,このプロセスゾーンを考慮した破壊勒性を評 価するためにはき裂進展量と破壊勒性との関係であ るき裂進展抵抗曲線(R曲線)を用いる必要がある.そこ で本研究では, R曲線による破壊勒性の評価について も一部の試験で併せて実施した.

\section{(1) SENRBB試験}

SENRBB 試験では,試験片を下部の 2 点を支点ロー ラで支え,上部を 1 点のローラで載荷することにより 曲げ荷重 $(F)$ を負荷した.破壊靭性の算出は,試験時に記 録した最大荷重 $\left(F_{\max }\right)$ および試験片直径 $(D)$,下部の支 点ローラ間の長さ $(S)$ を用いて次式により行なった ${ }^{8)}$.

$$
K_{I C}=0.25(S / D) \quad Y_{I}^{\prime} \quad F_{\max } / D^{1.5}
$$

ここで,式中の $Y_{I}^{\prime}$ は無次元化された応力拡大係数で あり次式で与えられる.

$$
\begin{aligned}
& Y_{I}^{\prime}=2(D / S)\left[450.8531 \rho^{2}(a / D)^{1.5}\right] /\left[(a / D)-(a / D)^{2}\right]_{(2)}^{0.25} \\
& \text { ここで, } \rho=(S / D) / 3.33 \text { である. }
\end{aligned}
$$




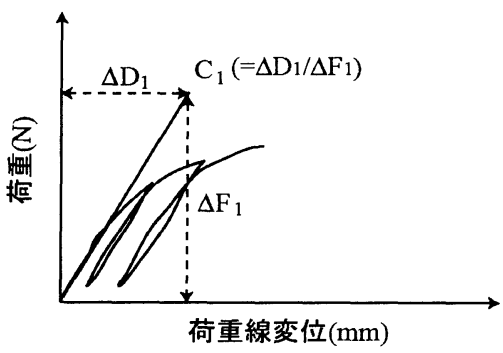

(a)ノッチ長さ $\mathrm{a}_{1}$ のときの荷重一荷重線変位曲線からの 弾性コンプライアンス $\mathrm{C}_{1}$ の算出

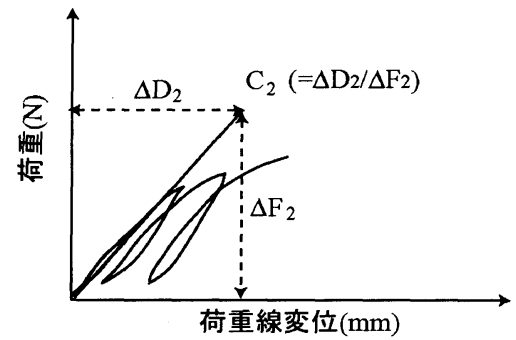

(b)ノッチ長さa 2 のときの荷重一荷重線変位曲線からの 弾性コンプライアンス $\mathrm{C}_{2}$ の算出

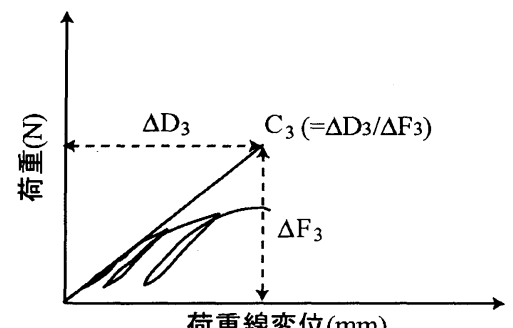

荷重線変位 $(\mathrm{mm})$

(c)ノッチ長さ $\mathrm{a}_{3}$ のときの荷重一荷重線変位曲線からの 弾性コンプライアンス $\mathrm{C}_{3}$ の算出

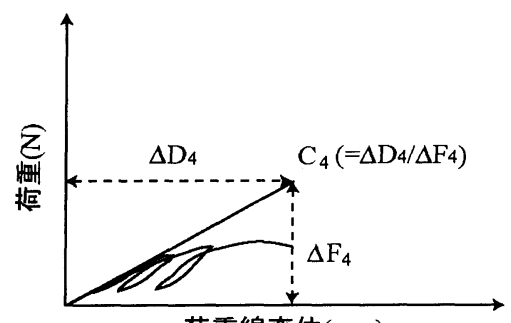

荷重線変位 $(\mathrm{mm})$

(d)ノッチ長さ $\mathrm{a} 4$ のときの荷重一荷重線变位曲線からの 弾性コンプライアンス 4 の算出

図-3 荷重一荷重線変位曲線からのコンプライアンス の算出

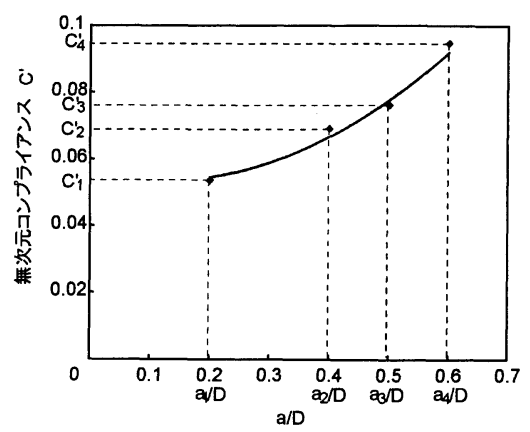

図-4＼cjkstart無次元コンプライアンスとき裂長さの較正曲線

（2）R曲線法による破壊勒性の評価

金属材料における R 曲線法は ASTM(American Society for Testing and Materials)によって E561-86 とし て規格化されている ${ }^{9}$.本研究で実施した R 曲線によ る破壊勒性の評価は,この方法に準拠して行なった.R 曲線法による破壊勒性の評価では,試験中のき裂の進 展推定するために,複数回の載荷一除荷一再載荷の繰 り返し載荷を行なうことにより得られる,荷重一荷重 線変位曲線を用いる.ここで述べる荷重線変位とは, 試験片と負荷ローラとの交線における変位である.R 曲線法による破壊靭性の評価は,事前にコンプライア ンスとき裂長さとの関係を示すための較正試験を以 下の(i) (iv)の手順で実施し ${ }^{10)}$,その後,実際の破壊靭性 試験結果を用いて,次の(v) -(xi)の手順で破壊勒性を評 価した。

(i) コンプライアンスとき裂長さとの較正曲線 を作製するために,図-2 に示すノッチ長さ $\left(a_{1} \sim a_{4}\right)$ の異なる複数の来待砂岩の試験片を準 備する.

(ii) この試験片に対して常温,大気圧下で繰り返 し載荷を行なう.図-3 にしめす荷重一荷重線 変位曲線が線形弾性挙動を示す第 1 回目の 載荷一除荷一再載荷（以下サイクルと呼 ぶ）時における除荷直線の傾きの逆数を弾 性コンプライアンス $\left(\mathrm{C}_{1} \sim \mathrm{C}_{4}\right)$ として評価する.

(iii) この弾性コンプライアンス $\left(\mathrm{C}_{1} \sim \mathrm{C}_{4}\right)$ を来待砂 岩の平面ひずみ変形係数 $\left(E_{\mathrm{t}, 50}{ }^{\prime}=E_{\mathrm{t}, 50} /\left(1-\nu^{2}\right)\right)$ と 試験片直径 $(D)$ を用いて無次元化し $\left(C^{\prime}=C E_{\mathrm{t}, 50}{ }^{\prime} D\right)$, 無次元コンプライアンス $\left(\mathrm{C}_{1}{ }^{\prime} \sim \mathrm{C}_{4}{ }^{\prime}\right)$ を算出する.

(iv) 図-4 に示すように試験片直径に対するノッ チ長さの比 $(a / D) を$ 横軸に,無次元コンプライ アンスを縦軸にプロットして最少二乗近似 により較正曲線を求める. 


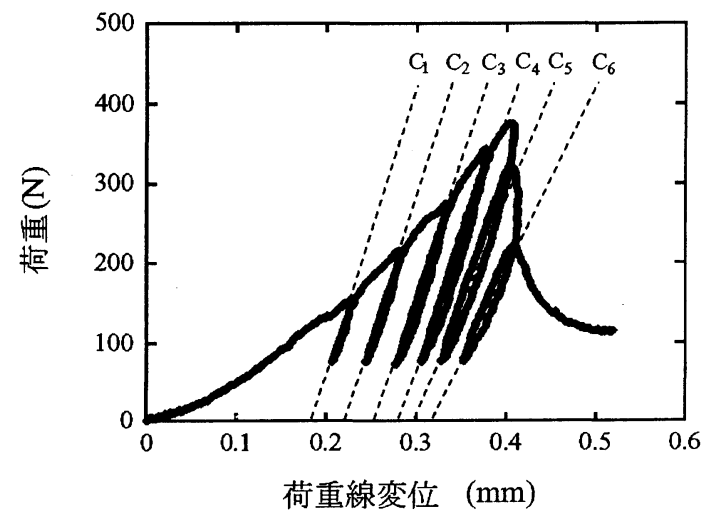

図-5 繰り返し載荷をして得られた荷重一荷重線変位曲 線と各サイクルからのコンプライアンスの評価

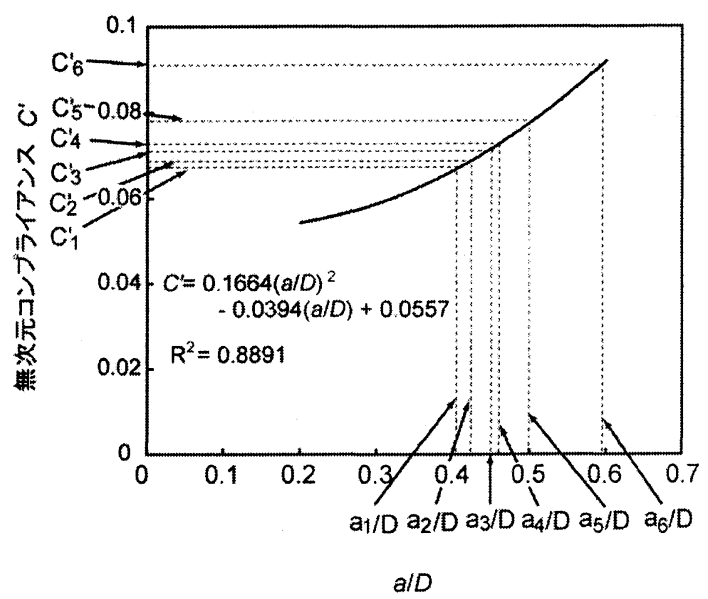

図-6 較正曲線を用いた無次元コンプライアンスから のき裂長さの推定

本研究で用いた形状の SENRBB 試験片の場合, 無次 元コンプライアンス $\left(C^{\prime}\right)$ とき裂長さ $(a / D)$ との関係は 次式で表わされる.

$$
\begin{aligned}
& C^{\prime}=0.1664(a / D)^{2}-0.0394(a / D)+0.0557 \\
& \mathrm{R}^{2}=0.889
\end{aligned}
$$

（v）次に, 温度または封圧下の破壊靭性試験で得 られた図-5に示す荷重一荷重線変位曲線の 各サイクルから,除荷直線の傾きの逆数を弾 性コンプライアンス $\left(\mathrm{C}_{1} \sim \mathrm{C}_{6}\right)$ として算出する.

(vi) (v)で求めた弾性コンプライアンス $\left(\mathrm{C}_{1} \sim \mathrm{C}_{6}\right)$ を, 平面ひずみヤング率 $\left(E_{\mathrm{t}, 50}{ }^{\prime}\right)$ と試験片直径 $(D)$ を

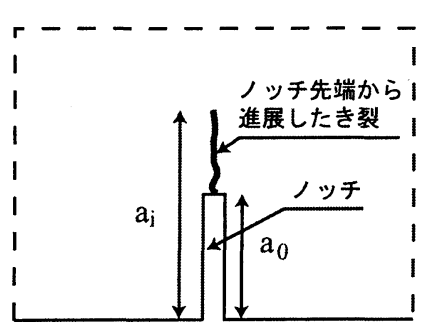

図-7 ノッチ先端から進展したき裂

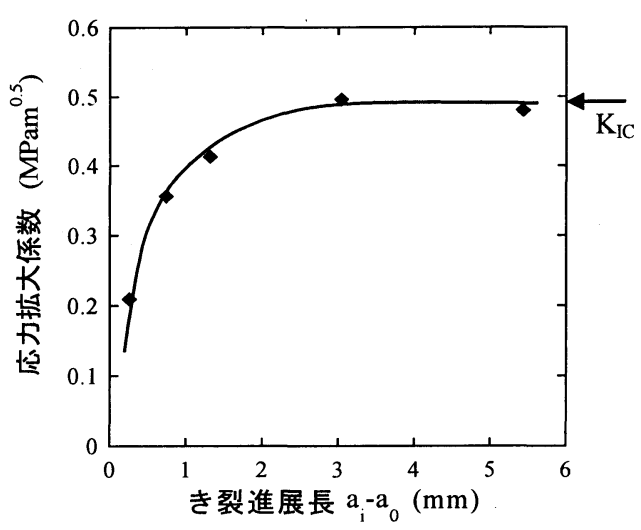

図-8Ｒ曲線からの破壊勒性の評価

用いて無次元化し $\left(C^{\prime}=C E_{\mathrm{t}, 50}{ }^{\prime} D\right)$, 無次元コン プライアンス $\left(\mathrm{C}_{1}{ }^{\prime} \sim \mathrm{C}_{6}{ }^{\prime}\right)$ を算出する.

(vii) (vi)で算出した無次元コンプライアンス $\left(\mathrm{C}_{1}{ }^{\prime} \sim \mathrm{C}_{6}{ }^{\prime}\right)$ を用いて各サイクルにおけるき裂長 さ $\left(a_{1} \sim a_{6}\right) を,(i) て ゙$ 求めた較正曲線から算出する (図-6 参照).

(viii) 各サイクルに対応するき裂長さ $\left(a_{1} \sim a_{6}\right)$ と除荷 開始時の荷重 $\left(\mathrm{F}_{1} \sim \mathrm{F}_{6}\right)$ を式(1),式(2)に代入して 各サイクルにおける応力拡大係数 $\left(\mathrm{K}_{1} \sim \mathrm{K}_{6}\right)$ を 算出する.

(ix) 各サイクルにおけるき裂長さ $\left(a_{1} \sim a_{6}\right)$ から初期 のノッチ長さ $\left(\mathrm{a}_{0}\right)$ をいた值を,き裂進展長 $\left(a_{1 \sim 6}-a_{0}\right)$ として算出する(図-7参照).

(x) き裂進展長を横軸に,応力拡大係数を縦軸に プロットし,図-8に示すき裂進展抵抗曲線を 描く.

（xi）（x)で描いたき裂進展抵抗曲線から,応力拡大 係数が一定となる值を,破壊靭性として評価 する(図-8 参照). 
表-1 来待砂岩と田下凝灰岩の物性値

\begin{tabular}{c|cccccc}
\hline & $\begin{array}{c}\text { 層理面と載荷,計測 } \\
\text { 方向との関係 }\end{array}$ & $q_{\mathrm{u}}(\mathrm{MPa})$ & $\sigma_{\mathrm{t}}(\mathrm{MPa})$ & $\begin{array}{c}E_{\mathrm{t}, 50} \\
(\mathrm{GPa})\end{array}$ & $\begin{array}{c}V_{P} \\
(\mathrm{~km} / \mathrm{sec})\end{array}$ \\
\hline \multirow{3}{*}{ 来待砂岩 } & $\perp$ & $59.0 \pm 2.5$ & $4.82 \pm 0.12$ & $8.23 \pm 1.43$ & $0.22 \pm 0.10$ & $2.91 \pm 0.02$ \\
& $/ /$ & $68.6 \pm 1.1$ & $4.89 \pm 0.40$ & $8.24 \pm 0.22$ & $0.16 \pm 0.01$ & $2.91 \pm 0.03$ \\
& $\perp$ & $23.9 \pm 2.0$ & $2.44 \pm 0.32$ & $3.33 \pm 0.18$ & $0.16 \pm 0.01$ & $2.00 \pm 0.08$ \\
田下凝灰岩 & $/ /$ & $20.3 \pm 0.7$ & $2.66 \pm 0.05$ & $2.24 \pm 0.93$ & $0.23 \pm 0.05$ & $2.40 \pm 0.08$ \\
\hline
\end{tabular}

$q_{\mathrm{u}}:$ 一軸圧縮強さ, $\sigma_{\mathrm{t}}:$ 圧裂引張り強さ, $E_{\mathrm{t}, 50}:$ 変形係数, $\nu:$ ポアソン比, $V_{\mathrm{P}}: \mathrm{P}$ 波速度

上：一軸圧縮試験,圧裂試験では層理面に対して垂直方向から載荷する．P 波速度測定では層理面に対して垂直に $\mathrm{P}$ 波を伝 播させる. $/ /$ : 一軸圧縮試験,圧裂試験では層理面に対して平行方向から載荷する. P 波速度測定では層理面に対して平行 にP波を伝播させる.

\section{3.試験の概要}

\section{(1) 岩石試料}

試験に用いた岩石は島根県産の来待砂岩と杤木県 産の田下凝灰岩である.SENRBB 試験片の準備におい ては,同一の岩石ブロックから層理面に対し平行な方 向と垂直な方向の 2 方向からコアボーリングを行な い,採取した岩石コアを図-1 に示した形状に整形した. なお図-1に示す SENRBB 試験片の寸法は $D=30 \mathrm{~mm}, L=110 \mathrm{~mm}, S=83.3 \mathrm{~mm}$, 温度条件下での試験で は $a=12 \mathrm{~mm}$ で封圧下での試験では $a=9 \mathrm{~mm}$ あり,ノッ チは厚さ $0.3 \mathrm{~mm}$ のダイヤモンドブレードで作製した. この試験片を乾燥させた後, 真空デシゲータの中で脱 気を行った.本研究において用いた両岩石の基礎的な 力学物性値を調べるために,一軸圧縮試験, 圧裂引張試 験,弾性波速度測定を行なった.一軸圧縮試験で用いた 試験片は直径 $\mathrm{D}=30 \mathrm{~mm}$, 長さ $\mathrm{L}=75 \mathrm{~mm}$, 両端面の平行度 が $11 / 50 \mathrm{~mm}$ 以内で整形したものである.なお,一軸圧 縮試験時に軸ひずみおよび横ひずみを計測するため に, ゲージ長 $5 \mathrm{~mm}$ の二軸型のひずみゲージを試験片 の相対する表面上の中心に 2 枚貼り付けた.図-9に一 軸圧縮試験から得られた応力ーひずみ線図の一例を 示す.同図に示すように,本研究では最大応力の $50 \%$ における応力一軸ひずみ曲線の接線の傾きを変形係 数 $E_{\mathrm{t}, 50}=\left(\sigma_{a}-\sigma_{b}\right) /\left(\varepsilon_{a}-\varepsilon_{b}\right)$ として算出し,同様に最大 応力の $50 \%$ における軸ひずみと横ひずみからポアソ ン比 $\nu=-\varepsilon_{\mathrm{L}} / \varepsilon_{\mathrm{A}}$ を算出した.

引張り強さを求めるための圧裂試験で用いた試験 片は,直径 $\mathrm{D}=60 \mathrm{~mm}$, 長さ $\mathrm{L}=30 \mathrm{~mm}$ 程度である.弾性波 速度測定に用いた試験片は,一軸圧縮試験に用いたそ れと同一のものを用いた.表-1 にこれらの物性試験の 結果を示す.同表によると,本研究において使用した来 待砂岩には異方性が存在した.例えば,来待砂岩の場合, 層理面に平行に載荷したときの一軸圧縮強さが,垂直

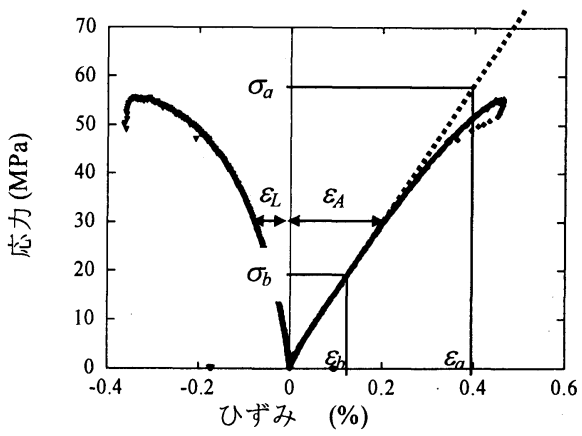

図-9＼cjkstart応力ーひずみ曲線の一例（来待砂岩）

に載荷したときと比べて約 $16 \%$ 大きい値を示した.ま た,田下凝灰岩の場合,層理面に垂直に載荷したときの 一軸圧縮強さが,平行に載荷したときと比べて約 $18 \%$ 大きい值を示した.また,弾性波速度では,層理面に平 行方向の值が垂直方向の值と比べて $20 \%$ 大きかった.

\section{（2）試験装置および試験手順}

破壊勒性試験で用いた試験装置の最大荷重容量は $19.6 \mathrm{kN}$ であり,本研究において設定可能な最高温度は $200^{\circ} \mathrm{C}$, 最大封圧は $30 \mathrm{MPa}$ である.試験では試験片をシ リコーンオイルで満たされた槽中に入れる必要があ ったため, シリコーンオイルがノッチや試験片内部の 空隙に浸入することを防ぐ目的で,ノッチおよび試験 片をシールした.シールの方法としては,ノッチの周り に紙製またはセロハン製のテープを巻いた後,その上 から試験片全体にシリコーン樹脂を均一に塗布した.

次に試験手順について述べる.まず,試験片を試験 用冶具にセットし,固定のため約 $0.5 \mathrm{~N}$ 荷重を負荷し た.次に,荷重および変位のゼロ点調整を行なった後, 試験槽内に試験片及び試験用冶具を納め試験槽を密 
閉した.その後,試験槽をシリコーンオイルによって満 たした.高温下の試験では,試験槽中のシリコーンオイ ルを加熱して所定の試験温度条件を設定した.試験温 度条件を設定する際,昇温速度が $200^{\circ} \mathrm{C} / \mathrm{h}\left(3.3^{\circ} \mathrm{C}\right.$ /min）以下では熱衝撃による破壊が起こらないこと が報告されていることから ${ }^{11)}$,本研究では熱衝撃によ る試験片の損傷を防ぐために昇温速度を約 $1^{\circ} \mathrm{C} / \mathrm{min}$ として加熱した.所定の温度に到達した後,試験片内部 の温度を均一にするために,その状態で 2 時間放置し た後,試験を開始した.試験片への荷重の載荷は,荷重 線変位速度を一定 $(0.075 \mathrm{~mm} / \mathrm{min})$ とした条件で行な い,荷重が最大荷重に到達した後残留強さ状態になる まで載荷を行なった.

本研究で設定した試験条件は,次の 2 種類である.1) 大気圧下で温度を変化させる.2)室温下で封圧を変化 させる.温度のみを変化させる試験では,温度を室 温, $50^{\circ} \mathrm{C}, 75^{\circ} \mathrm{C}, 100^{\circ} \mathrm{C}, 125^{\circ} \mathrm{C}, 150^{\circ} \mathrm{C}$, 及び $200^{\circ} \mathrm{C}$ の 7 条件変 化させた.封圧のみを変化させる試験では,封圧条件を 大気圧, $0.5 \mathrm{MPa}, 1 \mathrm{MPa}, 2.5 \mathrm{MPa}, 5 \mathrm{MPa}, 7 \mathrm{MPa}, 9 \mathrm{MPa}$ の 7 条 件変化させた.なお,荷重,荷重線変位,き裂開口変位,温 度および封圧のデータは,試験機からコンピュータに 送り,ディスクに保存した。

\section{（3）封圧下における破壊勒性の評価}

封圧下における破壊勒性試験法は,松木らにより提 案されており ${ }^{7}$,本研究では松木らの方法に準じて試 験を行なった.以下にその概略を示す。

前節 $3 \cdot 2 て ゙$ 述べたように, 本研究で用いた試験片に はシリコーン樹脂が塗布してある.そのため,図-10に 示すように,封圧を作用させる前の試験片のCODを 0mmとする(図-10(a)の状態)と,試験片に封圧を作用さ せた場合ノノッチ面と垂直に作用する封圧成分により 試験片に対し曲げモーメントが生じ,ノッチが閉じて しまう(図-10(b)の状態).そのため,試験片にある一定 の荷重 $\left(F_{1}\right)$ を載荷して,CODを初期の状態(図-10(c)の 状態)に戻してから試験を開始したこの一定の荷重 $F_{1}$ を補正荷重として試験時に得られた最大荷重 $F_{\text {max }}$ か ら引くことでノッチ面に封圧が作用しないことの影 響を取り除いた.補正荷重 $F_{1}$ は図-11に示す,COD - 荷 重曲線を用いて,封圧を課す前でCODが0 $\mathrm{mm}$ の初期状 態(図中(1),封圧を課してノッチが閉じた状態(図中(2)) から,試験片を載荷しノッチを初期の開口変位まで戻 したとき(図中(3))の荷重である.図-12に封圧と補正荷 重 $F_{1}$ との関係を示す.ただし,この方法では,一度ノッ チが閉じること,および,負荷した荷重 $F_{1}$ の影響により， 図-13に示すように,き裂長さが初期のノッチ長さ $(\mathrm{a} / \mathrm{D}=0.3)$ より成長している可能性がある.したがっ
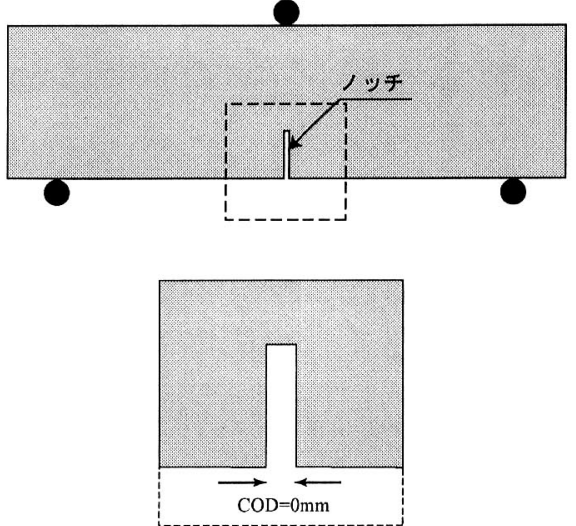

(a) 初期状態 (大気圧下)

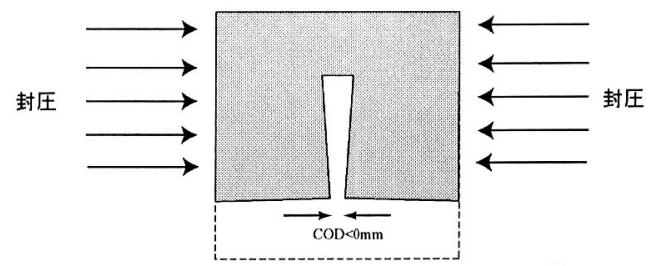

(b) 封圧によりノッチが閉鎖した状鎖

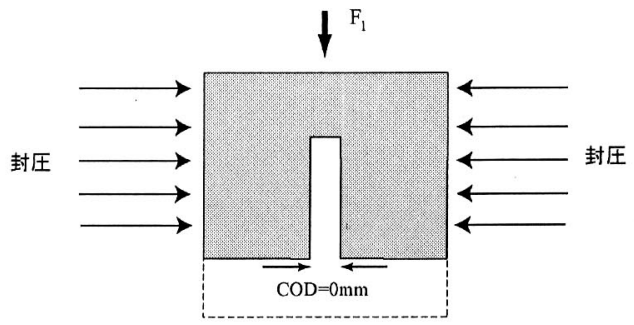

（c）封圧による閉鎖したノッチが荷重Fによより 初期の開口幅に戻った状態

図-10 封圧によるノッチの閉鎖と荷重 $\mathrm{F}_{1}$ によるノッ チの開口の模式図

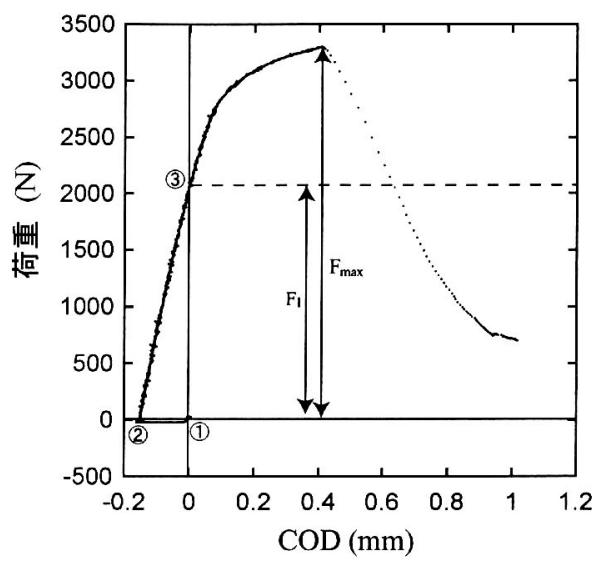

図-11 補正荷重 $F_{1}$ の算出に用いた荷重一COD 曲線の 一例(封圧 $7 \mathrm{MPa})$ 


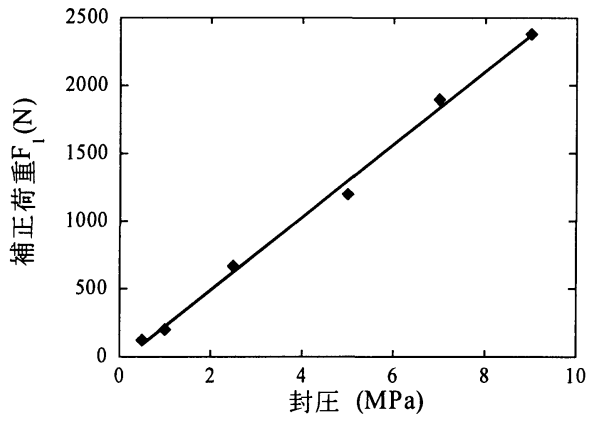

図-12 補正荷重と封圧との関係

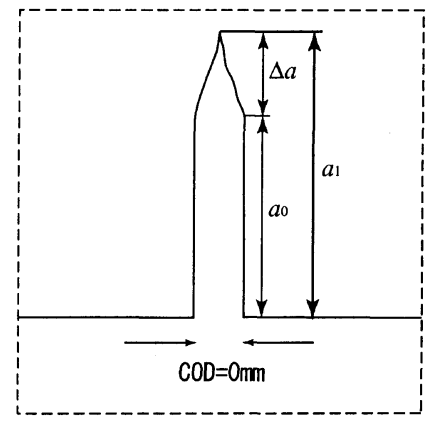

図-13 ノッチ先端からのき裂の進展

て,CODを初期の状態に戻した図-11中の(3)の時点に おけるき裂長さ $\left(a_{1}\right)$ を推定する必要がある.そのた め,2・2節の (v) - (ix)に記述した手順に従い,図-11中の (3)の時点で除荷一再載荷の繰り返し載荷を行い,その ときの除荷曲線からコンプライアンスを算出し,コン プライアンスとき裂長さの関係である式(3)からき裂 長さを算出したここれらの補正荷重 $F_{1}$ とき裂長さ $a_{1}$ を 用いて,式(1),式(2)を次の式(3),式(4)のように変形し,封 圧下の破壊勒性の評価を行なった.

$$
\begin{gathered}
K_{I C}=0.25(S / D) \quad Y_{I}^{\prime} \quad\left(F_{\max }-F_{1}\right) / D^{1.5} \quad \text { (4) } \\
Y_{I}^{\prime}=\frac{2(D / S)\left[450.8531 \rho^{2}\left(a_{1} / D\right)^{1.5}\right]^{p .5}}{\left[\left(a_{1} / D\right)-\left(a_{1} / D\right)^{2}\right]^{p .25}}, \rho=(S / D) / 3.33(5)
\end{gathered}
$$

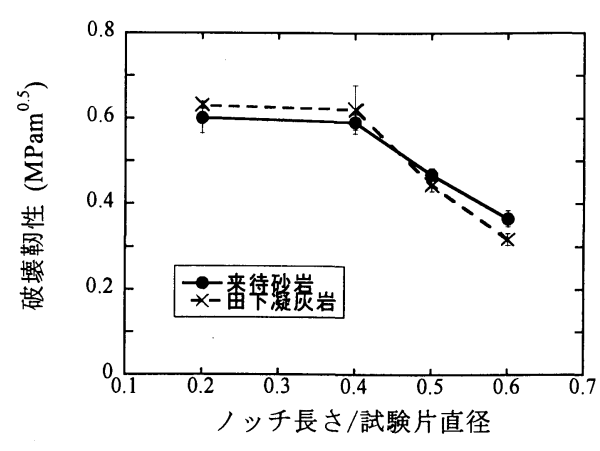

図-14 ノッチ長さと破壊靳性との関係 (層理面に垂直,温度 $25^{\circ} \mathrm{C}$,封圧 $0 \mathrm{MPa}$ )

\section{4.試験結果と考察}

本章では,まず,4・1節及び4・2節において来待砂岩, 田下凝灰岩の破壊勒性に及ぼすノッチ長さの影響と 荷重線変位速度の影響について,常温下で行った検討 結果について述べる.次に4・3節では,7種類の温度条件 の下で行った試験の結果と考察を述べる.最後に,4・4 節では,7種類の封圧条件下で行った試験の結果と考 察を述べる.すべての試験において同一条件で最低3 回試験を行なった.なお,図-14 21中の点は平均値で あり,バーは標準偏差の範囲である.

\section{（1）破壊勒性に及ぼすノッチ長さの影響}

岩石の破壊勒性に及ぼすノッチ長さの影響につい て検討するために,SENRBB試験片のノッチ長さ $(a)$ と 試験片寸法 $(D)$ の比 $(a / D)$ を $, a / D=0.2,0.4,0.5,0.6$ とした条 件で試験を行なった.図-14に $a / D$ と破壊勒性との関係 を示す.同図に示すように,来待砂岩,田下凝灰岩の破 壊勒性は,いずれも $a / D=0.2 \sim 0.4$ の範囲ではほぼ一定 の值を示した.一方, $a / D>0.4$ において破壊勒性はノッ チ長さの増加に伴い低下し, $a / D=0.5$ では,来待砂岩の 破壊勒性は $a / D=0.4$ のときの破壊勒性と比べて約 $21 \%$, 田下凝灰岩では約 $27 \%$ 低下した.さらに $a / D=0.6$ では, 来待砂岩の破壊勒性は約 $38 \%$,田下凝灰岩の破壊勒性 は約49\%低下した。 なお，この結果は，過去に行わ れた破壊勒性に及ぼすノッチ長さの影響に関する検 討 ${ }^{12)}$ と同様な傾向であった.

そこで本研究では, $a / D=0.2 \sim 0.4$ の範囲では,破壊勒 性がノッチ長さに依存しないことから,SENRBB試験 片のノッチ長さを温度条件下では $a / D=0.4$ と定めた. ただし,3・3節で述べたように,封圧下での試験では, 試験開始までにき裂の成長が生じることから,試験開 
示時における $\mathrm{a} / \mathrm{D} か ゙ 0.2 〜 0.4 の$ 範囲に収まるように $\mathrm{a} / \mathrm{D}=0.3$ とした.

\section{（2）破壊勒性に及ぼす載荷速度の影響}

岩石の破壊勒性に及ぼす変位速度の影響について 検討するため, $0.01 \mathrm{~mm} / \mathrm{min}, 0.05 \mathrm{~mm} / \mathrm{min}, 0.09 \mathrm{~mm} / \mathrm{min}$ の 3 種類の変位速度において試験を行なった.図-15 に,変位速度と破壊勒性との関係を示す.同図から分か るように,来待砂岩,田下凝灰岩の破壊勒性は,3 種類の 変位速度のいずれにおいても,ほぼ一定の值をとって おり,変位速度が $0.01 \mathrm{~mm} / \mathrm{min} \sim 0.09 \mathrm{~mm} / \mathrm{min}$ では破壊 靭性は変位速度に依存していない。

したがって,本研究では変位速度を $0.01 \mathrm{~mm} / \mathrm{min}$ $0.09 \mathrm{~mm} / \mathrm{min}$ の範囲から採用することにし, $0.075 \mathrm{~mm} /$ $\min$ とした.

\section{（3）破壊䩒性に及ぼす温度の影響}

$4 \cdot 1$ 節及び4・2節に述べたようにSENRBB試験で得 られた破壊勒性は， $a / D=0.2 \sim 0.4$ 範囲ではノッチ長 さの影響を受けず,また, $0.01 \mathrm{~mm} / \mathrm{min} \sim 0.09 \mathrm{~mm} / \mathrm{min} の$ 範囲では荷重線変位速度の影響を受けない.そこで, 温度条件下で実施した破壊靭性試験において, SENRBB試験片のノッチ長さを $a / D=0.4$, 荷重線変位 速度を $0.075 \mathrm{~mm} / \mathrm{min}$ とた。

図-16にSENRBB試験により得られた来待砂岩の破 壊勒性と温度との関係を示す.同図に示すように,来待 砂岩の破壊靭性は,温度が室温から $125^{\circ} \mathrm{C}$ 範囲でほ ぼ一定の值を示している.一方,温度が $125^{\circ} \mathrm{C}$ 以上にな ると,温度の上昇とともに破壊靭性が増加している.例 えば, $150^{\circ} \mathrm{C}$ ときの破壊靰性は室温のときの破壊勒 性と比べて約 $30 \%$ 増加しており, $200^{\circ} \mathrm{C}$ のきの破壊 勒性は室温のときの破壊靭性と比べて約 $40 \%$ 増加し ている.

図-17にSENRBB試験により得られた田下凝灰岩の 破壊靭性と温度との関係を示す.同図に示すように,田 下凝灰岩の破壊勒性は,室温から $50^{\circ} \mathrm{C}$ で破壊勒性の低 下が生じた後,層理面に垂直に載荷した場合は温度 $100^{\circ} \mathrm{C}$ て層理面に平行に載荷した場合には温度 $150^{\circ} \mathrm{C}$ 以上で,温度の上昇とともに破壊勒性は増加している.

温度の上昇に伴って破壊勒性が変化する要因とし ては,まず,温度の上昇により生じる鉱物粒子の熱膨張 が挙げられる. また,温度の上昇によって岩石中に存 在する粘土鉱物の含有している吸着水や層間水が脱 水することが要因として挙げられる.

前者には,例えばMeredith et al.による花崗岩と斑レ イ岩の破壊靭性が $100^{\circ} \mathrm{C}$ 以上で温度の上昇とともに低 下することを示した研究がある ${ }^{2)}$.Meredith et al.

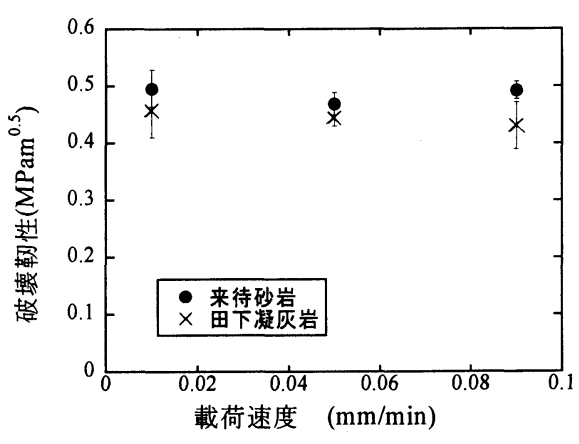

図-15 載荷速度と破壊勒性との関係

（層理面に垂直に載荷,温度 $25^{\circ} \mathrm{C}$,封圧 $0 \mathrm{MPa}$ )

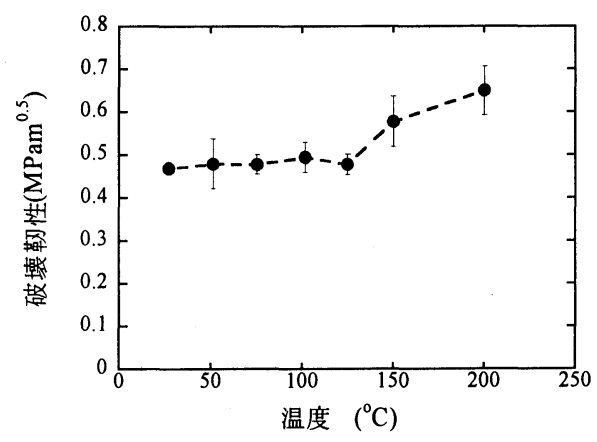

図-16 温度と破壊勒性との関係

(来待砂岩,層理面に垂直に載荷,封圧 $0 \mathrm{MPa}$ )

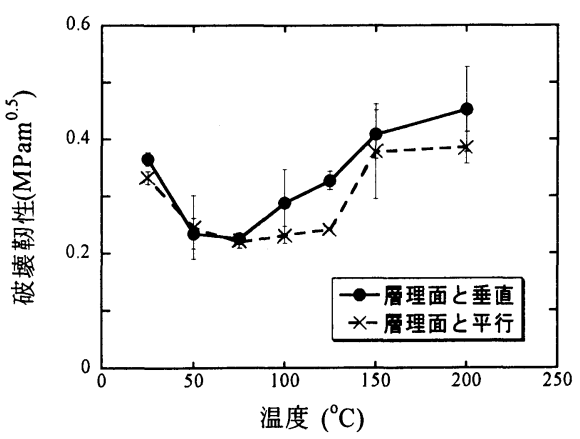

図-17 温度と破壊勒性との関係

(田下凝灰岩,封圧 $0 \mathrm{MPa}$ )

は, $100^{\circ} \mathrm{C}$ 以上における温度の上昇にともなう破壊靭 性低下の理由として, 温度の上昇により生じる構成 鉱物間の熱膨張の異方性が鈗物粒子間にマイクロク 
(圧縮)

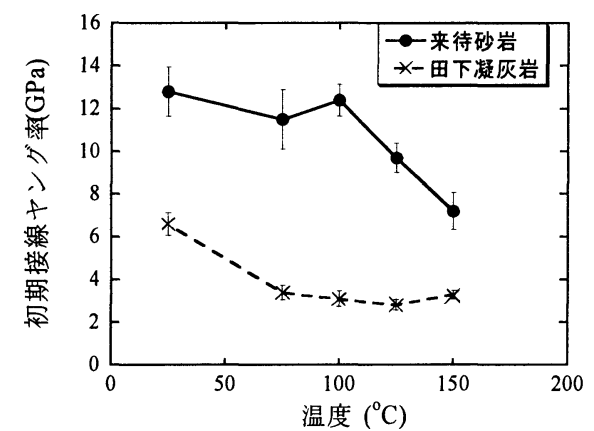

図-18 温度と初期接線ヤング率との関係(封圧 $0 \mathrm{MPa}$ )

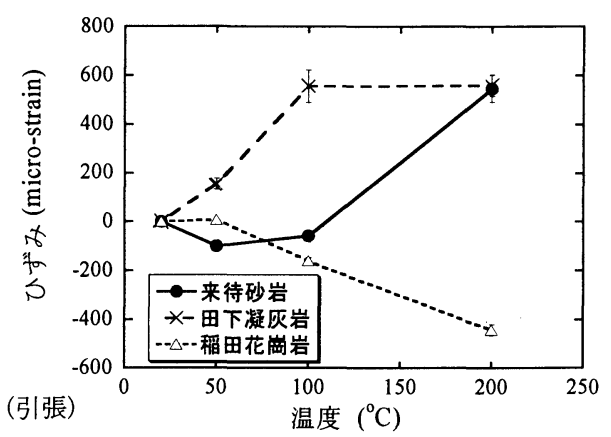

図-19 温度とひずみとの関係(封圧 $0 \mathrm{MPa}$ )
ラックを誘発し，それによってき裂の進展抵抗が低 下するためと考察している.そこで, 本研究で用いた 来待砂岩および田下凝灰岩に対し温度上昇によるマ イクロクラックの発生について検討するために, $75^{\circ} \mathrm{C}, 100^{\circ} \mathrm{C}, 125^{\circ} \mathrm{C}$, 及び $150^{\circ} \mathrm{C}$ の種類の異なる温 度条件下で一軸圧縮試験を行ない，温度によるヤン グ率の変化について調べた.試験片は直径 $20 \mathrm{~mm}$, 長 さ $45 \mathrm{~mm}$ の円柱形であり, $40^{\circ} \mathrm{C}$ に設定された乾燥器 内で試験片の重量の変化がなくなるまで乾燥させた 後脱気を行った.また，一軸圧縮試験時の軸ひずみを 計測するために，ゲージ長 $5 \mathrm{~mm}$ の高温用ひずみゲー ジを試験片の相対する表面上の中心に2枚貼り付けた 試験では，まず，破壊靶性試験と同一の昇温速度 $\left(1^{\circ} \mathrm{C} / \mathrm{min}\right)$ で設定温度に達するまで加熱し，その状態 で2時間放置した後に試験を行った。一軸圧縮試験に より得られた初期接線ヤング率と温度との関係を図一 18に示す.同図に示すように,来待砂岩の初期接線ヤン グ率は室温から温度 $100^{\circ} \mathrm{C}$ 範囲ではほぼ一定の值を とっているが, 温度 $100^{\circ} \mathrm{C}$ 以上では初期接線ヤング率 は温度の上昇にともなって低下寸ることが分かる.方,田下凝灰岩の場合, 温度 $75^{\circ} \mathrm{C}$ のきの初期接線ヤン グ率は室温のときと比べて約 $50 \%$ 低下しているが,温 度 $75^{\circ} \mathrm{C}$ から温度 $150^{\circ} \mathrm{C}$ 範囲では初期接線ヤング率は 温度に依存せず一定の值をとっている.初期接線ヤン グ率はクラック密度に依存するので13), ここで示し た初期接線ヤング率の低下は試験片内部でのマイク ロクラックの発生と密接に関係していると考えられ る.

次に, 温度の上昇にともなう試験片のひずみの変 化について検討するために, $50^{\circ} \mathrm{C}, 100^{\circ} \mathrm{C}, 200^{\circ} \mathrm{C}$ の 3 種類の温度条件を設定し, ひずみの計測を行った. ひずみの計測に用いた試験片は直径 $20 \mathrm{~mm}$, 長さ $45 \mathrm{~mm}$ の円柱形のもので, $40^{\circ} \mathrm{C}$ に設定された乾燥器
内で試験片の重量の変化がなくなるまで乾燥させた 後脱気を行った.ひずみゲージはゲージ長 $5 \mathrm{~mm}$ の高 温用ひずみゲージを試験片の相対する表面上の中心 に 2 枚貼り付けた.なお，加熱は破壊勒性試験と同一 の手法で行なった.図-19 に, 設定温度で 2 時間経過 した後の軸ひずみと温度との関係を示す.同図が示す ように, 稲田花岡岩の場合には, 室温から $50^{\circ} \mathrm{C}$ の範 囲でひずみはほとんど変化していない.しかしながら， 温度 $50^{\circ} \mathrm{C}$ 以上では温度の上昇とともに試験片が膨張 している.この結果は, 花崗岩では温度 $60^{\circ} \mathrm{C}$ から $70^{\circ} \mathrm{C}$ 前後からマイクロクラックが発生するとした研 究結果 ${ }^{14)}$ と調和的である.一方, 砂岩の場合には, 温 度 $50^{\circ} \mathrm{C}$ および $100^{\circ} \mathrm{C}$ では室温時の状態から試験片は 膨張しているが, 温度が $200^{\circ} \mathrm{C}$ まで上昇すると試験 片は収縮している.また,田下凝灰岩の場合には,温度 が $50^{\circ} \mathrm{C}$ から $100^{\circ} \mathrm{C}$ 一上昇する際に,試験片の顕著な収 縮が生じている.来待砂岩および田下凝灰岩は, 粘土 鉱物, 主としてモンモリロナイトを含んでいるが, モンモリロナイトは温度が $100^{\circ} \mathrm{C}$ から $250^{\circ} \mathrm{C}$ 程度に なると, 層間水や吸着水の脱水を起こすことが知ら れている ${ }^{15)}$.つまり, 温度の上昇によって試験片が収 縮する理由として, 温度の上昇とともに粘土鉱物か らの層間水や吸着水の脱水が発生していることが挙 げられる.また,ひずみの計測に用いた試験片の重量変 化を調べた結果, 温度 $100^{\circ} \mathrm{C}$ での試験後には来待砂 岩で $2.3 \%$, 田下凝灰岩で $1.3 \%, 200^{\circ} \mathrm{C}$ の試験後には 来待砂岩で 3.6\%,田下凝灰岩で $2.7 \%$ の重量低下が確 認できている.したがって，図-18 で示したひずみ測 定結果と併せて考えると, 試験温度が $100^{\circ} \mathrm{C}$ 以上の 条件では粘土鉱物からの層間水や吸着水の脱水が発 生したことにより, 試験片の重量低下と収縮が生じ たものと考えられる.また, 破壊勒性に及ぼす温度の 影響という点では, この粘土鉱物からの層間水や吸 


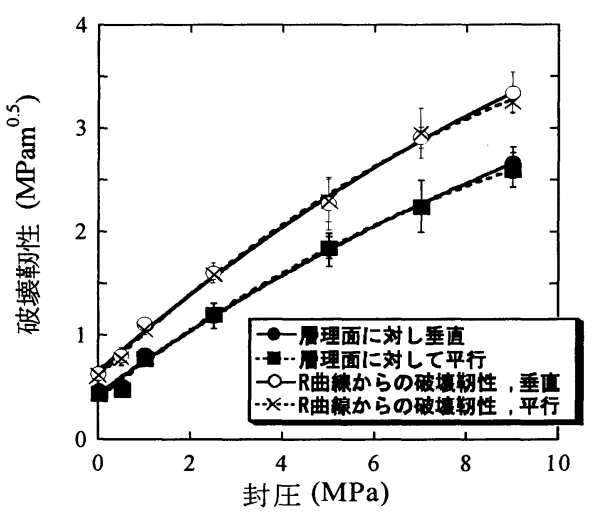

図-20 封圧と破壊鞋性との関係 (来待砂岩, 温度 $25^{\circ} \mathrm{C}$ )

着水の脱水によって粘土鉱物の乾燥・収縮による固 結化が発生し，これによって砂岩の構成粒子間の摩 擦倸数が上昇し破壊靭性が増加寸るものと考えられ る.

以上のように，来待砂岩および田下凝灰岩では破 壊勒性の低下の要因となるマイクロクラックの発生 と, 破壊勒性の増加の要因となる粘土鉱物の状態変 化の両方が生じている.ただし, 来待砂岩の破壊勒性 が温度 $125^{\circ} \mathrm{C}$ 以上で温度の上昇とともに増加したこ とを考慮すると, 来待砂岩の破壊勒性に及ぼす温度 の影響としてはマイクロクラックの発生よりも粘土 釷物の状態変化のほうがより支配的な要因であると 考えられる.一方, 田下凝灰岩の場合には, 室温から温 度 $50^{\circ} \mathrm{C} \sim 75^{\circ} \mathrm{C}$ 一と上昇したときに破壊勒性の低下が 生じており, その後, 温度 $100^{\circ} \mathrm{C}$ 以上で温度の上昇 とともに破壊勒性の増加が生じていることから，田 下凝灰岩の場合には室温から温度 $50^{\circ} \mathrm{C} \sim 75^{\circ} \mathrm{C}$ の範囲 では熱収縮に伴うマイクロクラックの発生が粘土鉱 物の状態変化より支配的であったのが, 温度 $100^{\circ} \mathrm{C}$ $\sim 125^{\circ} \mathrm{C}$ 以上になると, 来待砂岩と同様に粘土鉣物 の状態変化がより支配的な要因となったものと考え られる。

\section{（4）破壊勒性に及ぼす封圧の影響}

図-20にSENRBB試験により得られた来待砂岩の破 壊勒性と封圧との関係を示す. 同図に示すように, 来待 砂岩の破壊勒性は封圧の上昇に伴い増加している.た だし,封圧5MPaを境界に封圧の上昇に伴う破壊鞋性 の増加率が異なり,封圧が $5 \mathrm{MPa}$ 以上では封圧の上昇 に伴う破壊鞋性の増加率が低くなっている.また,R曲 線による破壊勒性の場合においても,封圧 $2.5 \mathrm{MPa}$ 境

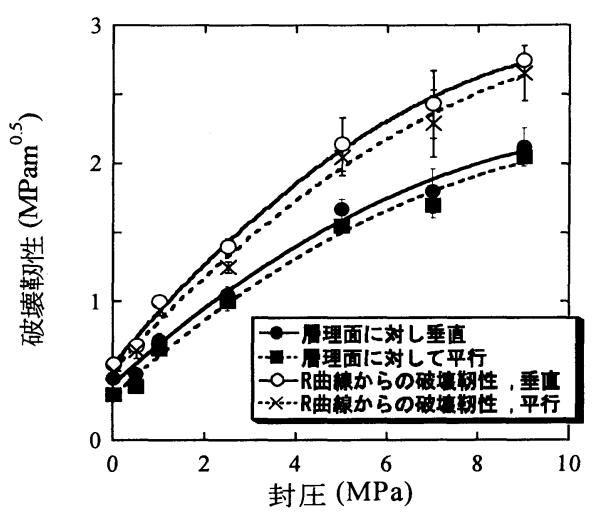

図-21 封圧と破壊勒性との関係 (田下凝灰岩, 温度 $25^{\circ} \mathrm{C}$ )

界として,封圧2.5MPa以上では封圧の上昇に伴う破壊 勒性の増加率の低下傾向が見られる.

図-21にSENRBB試験により得られた田下凝灰岩の 破壊勒性と封圧との関係を示す.同図に示すように,田 下凝灰岩の場合にも来待砂岩の場合と同様,破壊鞋性 は封圧の上昇に伴い増加しており,封圧の上昇に伴い 破壊勒性の増加率は低下寸る傾向が見られた.

封圧による破壊勒性の増加の要因として, 松木ら は, 封圧によって潜在き裂が閉じ摩擦力が作用するこ とで, 大気圧下に比べてノッチ面に垂直な引張応力 のみでは潜在き裂は開口しにくくなり，き裂の成長 に対する抵抗が大きくなると考察している77. また， 封圧下における破壊の形態が延性的なものに変化す ることも破壊勒性の増加の要因として挙げられる.一 般に，封圧下では引張き裂の発生は抑制され，せん 断クラックが生じるようになるとされている ${ }^{16}$.その 結果, 大気圧下ではマイクロクラックの発生, 成長 に基づく破壊形式が封圧下ではすべり面分離がき裂 の先端で生じ,荷重一荷重線変位曲線の非線形挙動に つながったものと考えられる.また,この非線形挙動の 部分ではき裂の安定成長が生じており,このことがき 裂の進展抵抗の増加に結びついたものと考えられる.

松木らの研究では,岩石のき裂進展抵抗に及ぼす封 圧の影響のひとつとして,封圧の上昇に伴い異方性が 顕著になることが示されている7?.それに対して,本研 究の結果では封圧が9MPaまでの範囲では来待砂岩, 田下凝灰岩ともに封圧の上昇に伴う異方性の顕著化 は確認されなかった。 


\section{5.結論}

本研究では,岩石の破壊勒性に及ぼす温度および封 圧の影響について明らかにするために,SENRBB試験 を行なった。

その結果,

1)来待砂岩の破壊勒性は温度が $125^{\circ} \mathrm{C}$ ま゙の範囲で は,ほぼ一定の值を示すのに対し, $125^{\circ} \mathrm{C}$ 以上では温度 の上昇に伴って破壊勒性は増加した.

2)田下凝灰岩の破壊靭性は,温度が室温から $50^{\circ} \mathrm{C}$ 一 上昇すると减少したが,温度が $100^{\circ} \mathrm{C} \sim 125^{\circ} \mathrm{C}$ 以上にな ると温度の上昇に伴い破壊勒性も増加した。

3)温度の上昇にともなう破壊勒性の変化の要因と して, 温度の上昇にともなうマイクロクラックの発 生による破壊靸性の低下と, 粘土鉣物に存在してい る吸着水や層間水が脱水するために起こる粘土鉣物 の状態変化による破壊勒性の増加の二つが挙げられ る.

4)来待砂岩,田下凝灰岩の破壊靱性は封圧の上昇と ともに増加したが,封圧がある值以上になると封圧の 上昇に対する破壊鞋性の増加率は低くなる傾向が見 られた.

5)封圧の上昇にともなう破壊勒性の増加の要因と して,封圧による潜在き裂の閉鎖と破壊挙動の延性化 が挙げられる.

6)最大封圧9MPaまでの範囲では,来待砂岩および田 下凝灰岩の破壊鞋性の異方性は封圧にかかわらず一 定であった。

\section{参考文献}

1) 原子力委員会: 原子カバックエンド対策専門部会資 料, $7 \mathrm{p}, 2000$.

2) Meredith, P.G. and Atkinson, B.K.: Fracture toughness and subcritical crack growth during high-temperature tensile deformation of Westerly granite and Black gabbro, Physics of the Earth and Planetary Interiors, 39, pp.33-51,1985.

3) Al-Shayea, N.A.,Khan, K. and Abduljauwad, S.N.: Effects of confining pressure and temperature on mixed-mode(I-II) fracture toughness of a limestone rock, International Journal of Rock Mechanics and Mining Sciences, 37, pp.629643,2000.

4) 小林良二,大塚尚寛 : 封圧下における岩石の破壊勒性, 日本鉱業会誌,96（1114）,pp.879-884,1980.

5) 石塚与志雄,木下直人,安部透 : 岩石のき裂進展特性と 破壊勒性特性に関する研究, 土木学会論文集,338/III8,pp.103-110,1987.

6) Vasarhelyi, B.: Influence of pressure on the crack propagation under mode I loading in anisotropic gneiss, Rock Mechanics and Rock Engineering, 30(1), pp.59-64,1997.

7) 松木浩二,金子高久,佐藤稔紀 : 封圧下における岩石の き裂進展抵抗曲線,資源と素材,111,pp.755-760,1995.

8) Ouchterlony, F.: Extension of the compliance and stress intensity formulas for the single edge crack round bar in bending. ASTM STP 745: pp.237-256,1981.

9) ASTM E561-86: Standard Practice for R-CURVE DETERMINATION, Annual Book of ASTM Standards, Section 3, pp.793-813,1987.

10) 國尾武：破壊力学実験法,朝倉書店(東京),pp.136142,1984 .

11）山口梅太郎,宮崎道雄 : 熱による岩石の強度の変化あ るいは破壊について,日本鉣業会誌,86(986),pp346351,1970 .

12) Sun, Z. \& Ouchterlony, F. Fracture toughness of Stripa granite cores. Int. J. Rock Mech. Min. Sci. \& Geomech. Abstr., 23: pp.399-409,1986.

13) Lama, R.D. and Vutukuri, V.S.:岩石·岩盤技術書のた めのハンドブック 岩の力学的性質 II, 古今書院(東京), 92p.,1992.

14) 木下直人,安部透,若林成樹,石田毅 : 高温下の岩石の力 学特性に関する研究,土木学会論文集,561/III-38,pp.151162,1997 .

15) 図解応用地質用語編集委員会: 図解用語集シリーズ 図解応用地質用語集:東洋書店(東京),501p.,1985.

16) 日本材料学会:岩石力学一基礎から応用まで:丸善出版 （東京）,pp.92-93,1993.

\title{
EFFECT OF TEMPERATURE AND CONFINING PRESSURE ON FRACTURE TOUGHNESS OF SEDIMENTARY ROCK
}

(2002. 7. 8. 受付)

\author{
Takahiro FUNATSU, Masahiro SETO, Hideki SHIMADA and Kikuo MATSUI
}

In order to understand the combined effect of elevated temperature and confining pressure on fracture toughness, fracture toughness experiments were carried out (1) at elevated temperatures from room temperature to $200^{\circ} \mathrm{C},(2)$ at confining pressure from atmospheric pressure to $9 \mathrm{MPa}$ using the single edge-notched round bar in bending (SENRBB) specimen of Kimachi sandstone. The experimental results showed that the fracture toughness of Kimachi sandstone did not vary significantly at temperature up to $125^{\circ} \mathrm{C}$ and increased with elevated temperature beyond $125^{\circ} \mathrm{C}$. The fracture toughness of sandstone and tuff was found to be significantly affected by increasing confining pressure. 